\title{
INTERNATIONAL INTEGRATION OF EDUCATION WITHIN THE SCO FRAMEWORK: A DRIVING FORCE FOR JOINT CONSTRUCTION OF THE 'SILK ROAD ECONOMIC BELT'
}

\author{
Cao Huilin \\ Saint Petersburg State University.
}

\begin{abstract}
The 'Silk Road Economic Belt' (SREB) project was presented by Xi Jinping in the autumn of 2013 in Kazakhstan. The goals of building the Silk Road Economic Belt coincide with the objectives of the Shanghai Cooperation Organization (SCO). The SREB initiative got a positive response from the SCO member states. Humanistic cooperation, especially in the field of education, is becoming one of the fastest growing areas of cooperation within the SCO. The SCO University (USCO), as a form of the integration process within the SCO framework, is an important driving force for the implementation of the Silk Road Economic Belt initiative. In this paper, the results of education cooperation between the universities within the SCO are analyzed; deficiencies and imbalances in talent cultivation are pointed out. The study is based on the methods of quantitative, qualitative and comparative analysis. In order to identify the problems and obstacles in talent cultivation and to propose solutions, the method of questionnaire is used. The paper discusses the results of the integration of education within the SCO framework and the role of the USCO in developing cooperation between the member states, as well as the challenges faced by the participant countries in implementing the strategy of international integration of education.

Keywords: international integration of education; Shanghai Cooperation Organization; SCO University; Silk Road Economic Belt; cooperation of education; student exchange; driving force.
\end{abstract}

\section{Theoretical basis of the "international integration of education"}

In the context of globalization in all regions and states, in all areas of society, the process of world integration is taking place, therefore, new integration groups and international organizations are emerging. Experts in many fields such as economics, politics, culture, finance and others are drawn attention to the study of the integration processes, which are a special type of interaction between sovereign states. What is more, international integration, as an interdisciplinary concept, attracts interests in various fields of scientific research. 
There are many interpretations of the term "integration" by different area scientists. In the Big Encyclopedic Dictionary, the word "integration" (lat. Integratio-restoration, replenishment, frominteger-whole) is defined as 1) a concept, which means a state of connectedness of separate differentiated parts and functions of a system, an organism into a whole, as well as a process leading to such a state; 2) the process of convergence and communication of sciences, the process occurring along with the processes of their differentiation. ${ }^{1}$

Integration appeared before the XX century. However, "International integration", as a form of cooperation in the field of education, appeared in the last few years of the 20th century. In the framework of the educational process, the term "integration" can be explained as a country entry into the international educational space, which would be aimed at considering integration issues of educational institutions, as well as researching various teaching methods within the framework of one educational institution and the whole educational sector, which is implemented not only by different educational institutions of the same level, but also at different levels, among them, these institutions are not limited to belonging to one country (Abramova, 2014).

Integration of education is an all-round convergence of national educational systems. The complementarity between different education systems makes education a global social system. That means that within the framework of educational integration it is possible to create an international educational space, to provide an open, multilingual, diversified learning environment for sharing new knowledge and spreading national culture.

Within the framework of the international education integration, there is a tendency of international cooperation between educational institutions and educational organizations, as well as the emergence of supranational organizations, programs and funds. The process of international cooperation has affected the field of higher education in such a way that the main direction of the development of universities is now to enter the international arena, enter the created educational space, creating a network of international interaction of universities (Higher school..., 2018).

Integration of education is a way to create high-quality education in a country, as well as a form of cooperation among countries. The process of international education integration is relevant for the development of cooperation among leading universities in the region. In addition, it is also a special way to meet the demands of economic globalization and regional integration. The most representational regional integration educational initiative is the Bologna process in Europe. The Bologna Process is a series of ministerial meetings and agreements among European countries to ensure comparability in the standards and quality of higher-education qualifications. It is named after the University of Bologna, where the Bologna declaration was signed by education ministers from 29 European countries in $1999^{2}$. The "Bologna Process" aims at the development of an integrated and coherent European Higher Education Area. The main changes envisaged by the process involve a harmonization of the structure of mutual recognition of degrees (Cappellariet et al., 2009).

www.вокабула.pф/энциклопедии/Большой-энциклопедический-словарь/интеграция.

https://en.wikipedia.org/wiki/Bologna_Process 
The main direction of the education integration is to continue studying in any of the universities of this organization or group without any difficulties. It should be noted that the integration processes in the economic sphere gave an impetus to the increase in the territorial mobility of the labor force: it becomes necessary to form a unite educational space, to establish a mechanism of recognition and identification of education certificates, professional qualifications in various countries (Bushmeleva, 2015).

International integration of education is carried out through international cooperation, that is by signing agreements and contracts on education issues within the frame of the official education program regional organization with foreign partner institutions. For example, The SCO University was established within the framework of the Shanghai Cooperation Organization.

\section{SCO University - a special form for the implementation of international integration of education}

The Shanghai Cooperation Organization (SCO) is a permanent intergovernmental international organization. Seventeen years of the SCO development has led it to be an important platform and a comprehensive international organization for solving problems in security, military, economic and cultural fields in Europe and Asia. The existence of the SCO provides a real platform for humanitarian cooperation among Russia, China and the Central Asian countries. The humanitarian cooperation is one of the priority areas of interstate cooperation within the framework of the SCO. Cooperation in the cultural and humanitarian spheres promotes mutual understanding among the member states, strengthens friendship and political mutual trusts, creates favorable conditions for the formation of common values and cultural identity, as well as reduces barriers of cooperation in the fields of economic and security. In the final analysis, the competition of state power on the international stage lies in the reserve of innovative talents. In particular, international education integration plays an important role in the process of strengthening state power and influence.

The agreement on cooperation in the field of education signed in June 2006 between the governments of the SCO member states became the legal basis for the development and strengthening of interactions in this field. In August 2007, at the SCO summit in Bishkek, the President of the Russian Federation launched the initiative to create the SCO University (USCO), which is supported by Kazakhstan, China, Kyrgyzstan and Tajikistan (Uzbekistan refused to participate). Furthermore, in October 2008, the concept of creation and functioning of the SCO University was signed at the Education Ministerial Meeting of the SCO member states (in Astana).

The SCO University is a special form of supranational institutions for coordinating and managing educational integration in this region. Its creation embodies the trend of integrating education within the SCO framework. The objectives of the creation of the SCO University are defined within the SCO framework by the multilateral legal acts adopted by the SCO member states as follows: 
- strengthening mutual trust and good-neighborly relations between the SCO member states;

- development of integration processes in the field of education, science and technology;

- providing new impetus to expand multilateral education, science and cultural cooperation;

- expanding opportunities for young people to receive high-quality modern education, and for teachers and scientists - to develop scientific contacts;

- promotion of effective cooperation of the member states of the Organization in the political, trade, economic, scientific, technical and cultural fields (The SCO University..., no date).

Currently, the University unites 74 universities in 7 priority areas, such as energy, ecology, information technology (IT-technology), regional studies, nanotechnology and pedagogy. The SCO University consists of 73 leading universities from 5 SCO member states: Kazakhstan, China, Kyrgyzstan, Russia and Tajikistan. ${ }^{3}$

Some scientists believe that the acceleration of the integration process in the educational sphere should be carried out on the basis of unification of the most important areas of work of national education systems (Boichenko, 2007), and also with creation of a unified education space. In addition, the student exchange mechanism was implemented on the basis of the Agreement on the implementation of master's and bachelor's programs within the SCO University framework, which meet the standards of the two countries. Therefore, it creates the conditions for carrying out uniform curriculum programs for the SCO University in the relevant areas.

On the Russian side, since the establishment of the SCO University 1759 budget places were allocated for training in Russian universities in joint masters training programs within the SCO University, also, 350 budget places were provided in the 2018/2019 academic year (The allocation of budget ..., 2018). In accordance with the decree of the Ministry of Education and Science of the Russian Federation dated September 28, 2017 No. P-633, 130 budgetary places were allocated in the 2017/2018 academic year for the admission of foreign citizens to joint educational programs of the SCO University (SCO University), including Kazakhstan - 85 places; Kyrgyzstan -28 places; Tajikistan-17 places. It should be noted that some students, including 113 students from China, received budget places to study at Russian educational organizations within the SCO programs in the framework of the general competitive selection of foreign citizens to study in the Russian Federation (The disposal of the Ministry..., 2018).

From the Chinese side, The SREB initiative advances the education integration processes forward. The training of highly qualified personnel in China and other countries is carried out mainly through a joint program at the master's level. Russian and Chinese will be the official languages of the SCO, and in exceptional cases, it will be English.

The main models are presented as follow:

1. For Chinese students, there are two options:

3 http://uni-sco.ru/country/2/country_2.html 
The first option: the program " $2+1$ ". 2 years of study at the university in China, one-year study at the university in other participating countries.

The second option: the program " $2.5+1$. ." 2,5 years of study at the university in China, 6 months of study at the university in the participating countries.

2. For students from Russia and Central Asian countries, China also provided 2 options:

The first option: the program " $1+1$ ". One-year study at the university in their countries, one-year study at the university in China.

The second option: the program " $1.5+0.5$." 1.5 year of study at the university in their countries, 6 months of study at the university in China.

The reason is that in China the master program usually lasts 3 years, however, in the other SCO member countries it lasts 2 years. After graduation, students can receive a certificate from the SCO University and a certificate from the university where they studied. It should be noted that in some participating education institutions within the SCO framework the "Double Degree" mechanism is already being implemented, that means that students can receive both Russian and Chinese diploma. In addition, there is a joint training program at the bachelor's level within the SCO University framework. In 2015 , the joint preparation of bachelors in the " $2+2$ " program begun between Chinese and Russia universities. That is 2 years at a Chinese university and 2 years at a Russian university. This program is carried out only between the Dalian University of Foreign Languages and several Russian universities, however, it has already achieved great success. From 2015 to 2018 already 40 undergraduate students studied with the Major Orientation of "Foreign Regional Studies" under this program within the framework of the USCO in Russian universities, including 14 graduates who have already received double degrees, Chinese and Russian. Most graduates are getting their master degree in both China and Russia.

In this paper through specific data that gives a detailed analysis of the situation of cooperation in the field of education within the SCO framework and the achievements of this cooperation. The results are shown in the following charts:

Chart 1: The Geographical location map of the countries involved in the program of the SCO University

The member States of SCO

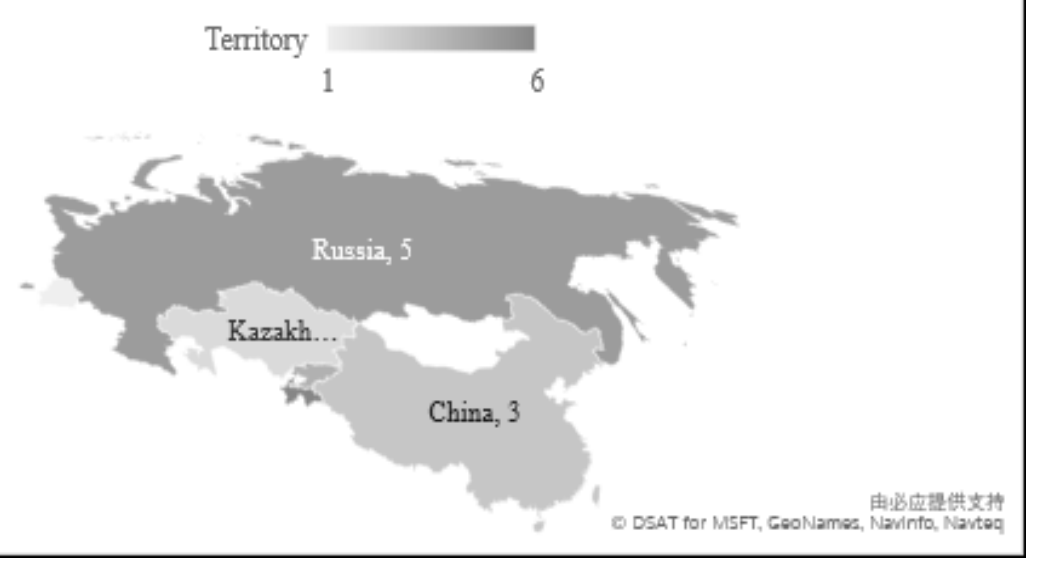


Chart 2: The total number of participating universities in the states in the USCO

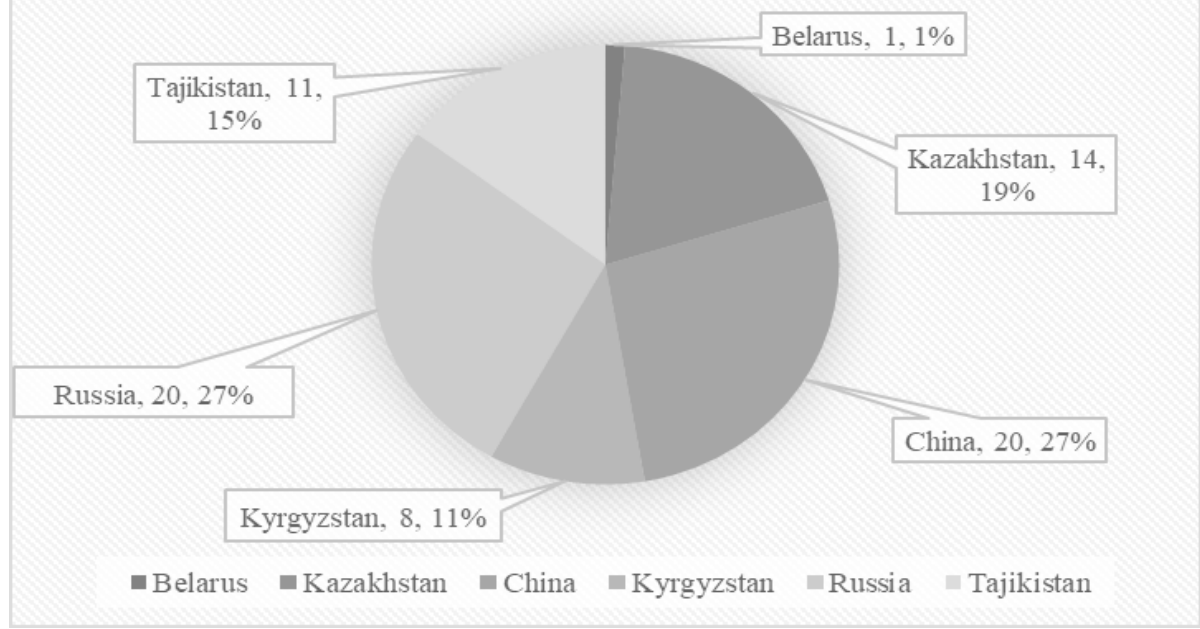

(participating universities, number, percentage)

Chart 3: The quantity dynamic of master students sent by Chinese universities to the universities of the member states within the USCO framework (2012-2017)

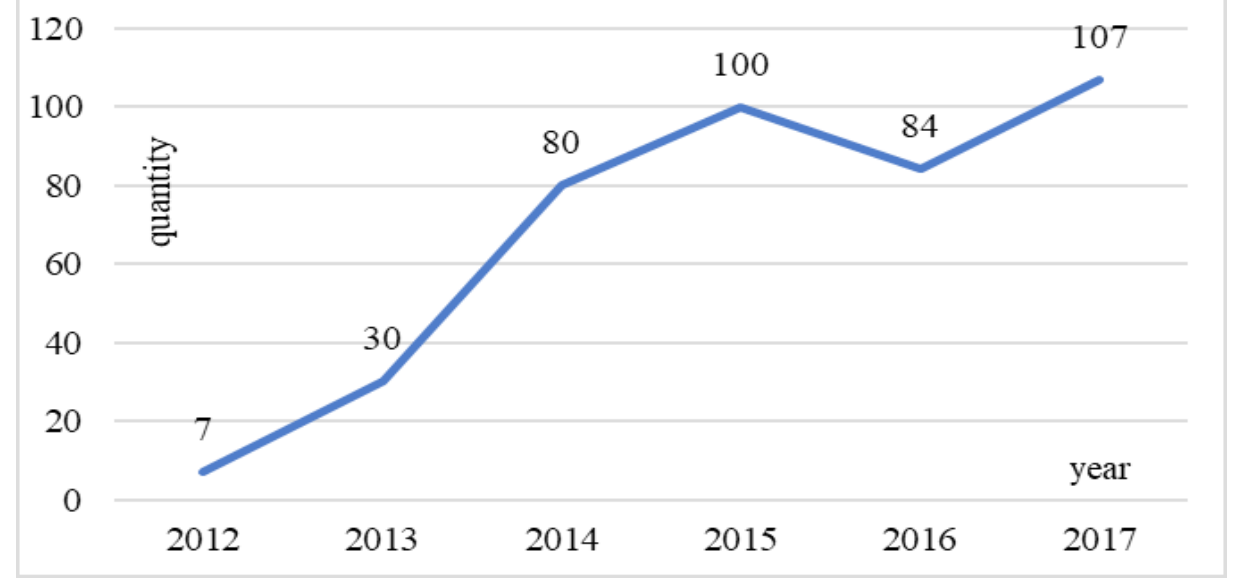

Chart 4: The quantity dynamic of master students accepted by Chinese universities from universities of the Member States within the framework of the SCO University (2012-2017)

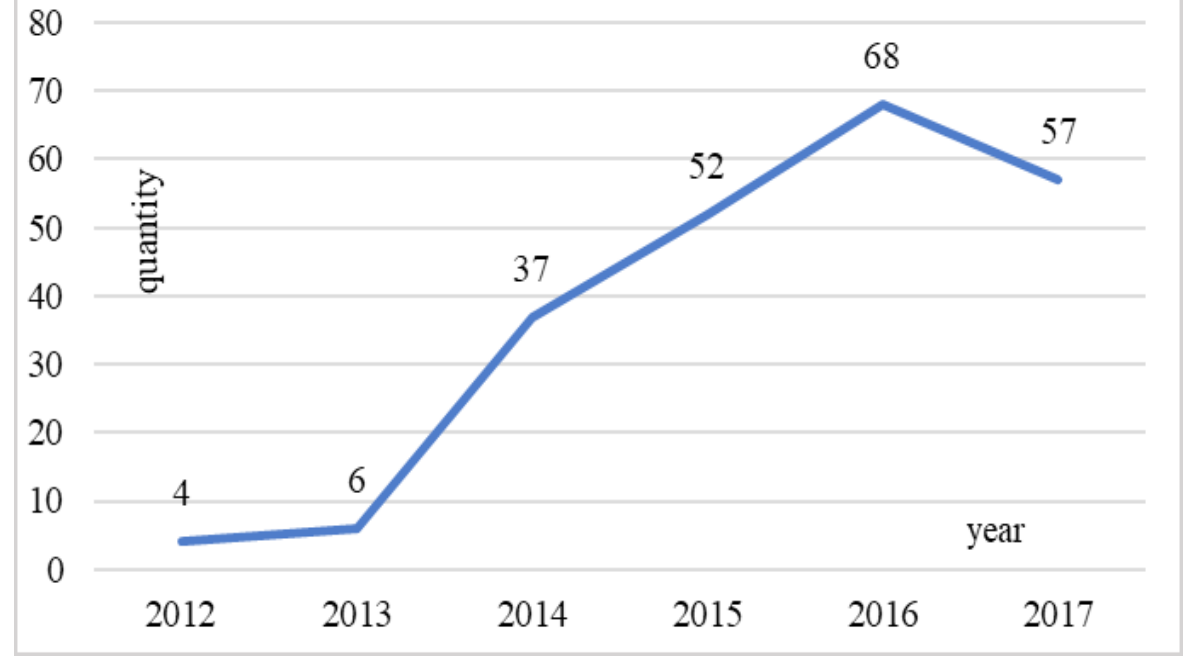


Chart 5: The total number of Chinese master students abroad in seven Major Orientations for 6 years

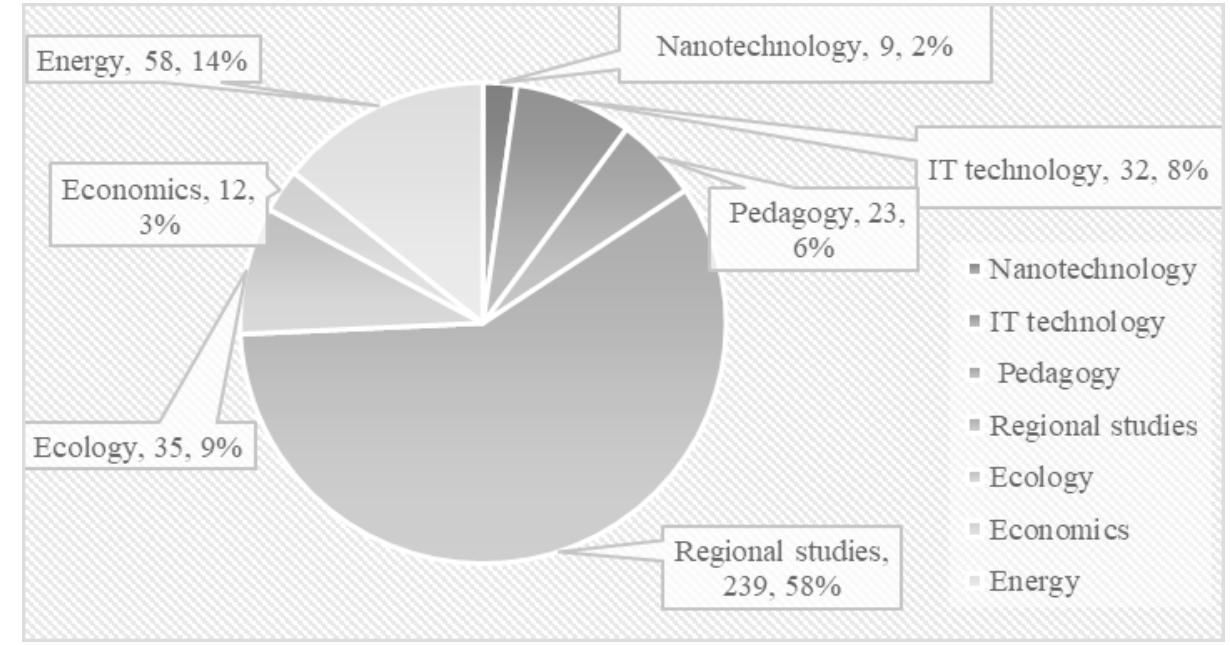

(Major Orientation, number, percentage)

Chart 6: The total number of foreign master students in China in seven Major Orientations for 6 years

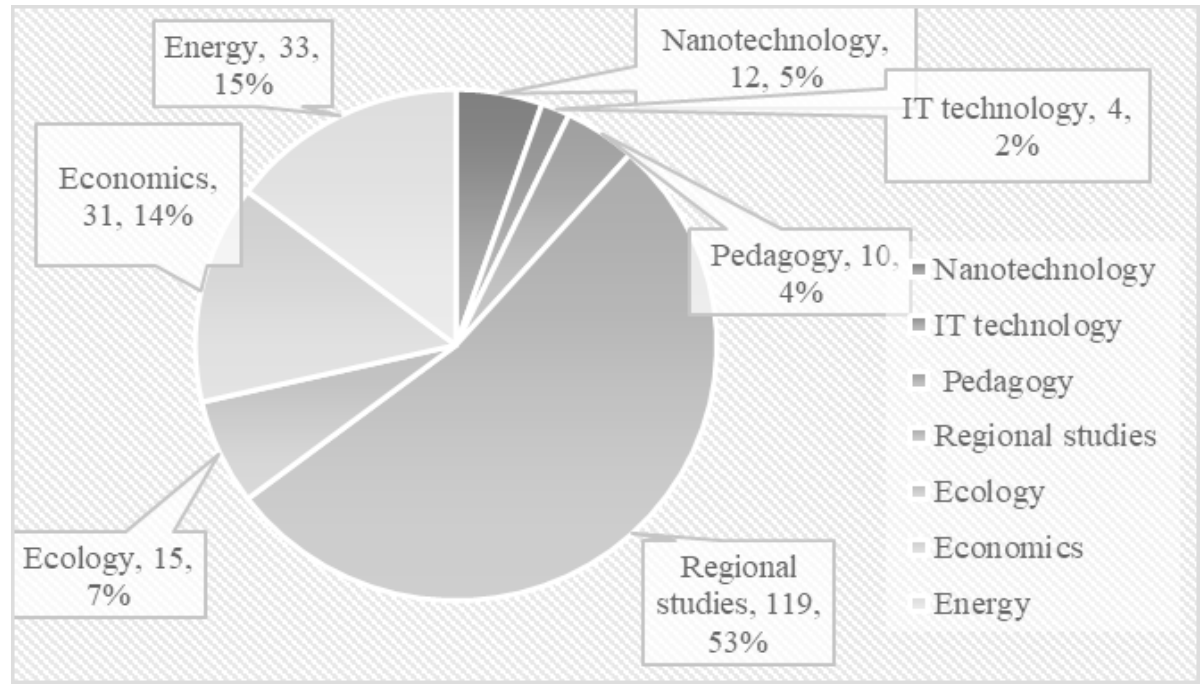

(Major Orientation, number, percentage)

Chart 7: The total number of Chinese master students studied in member states in 6 years

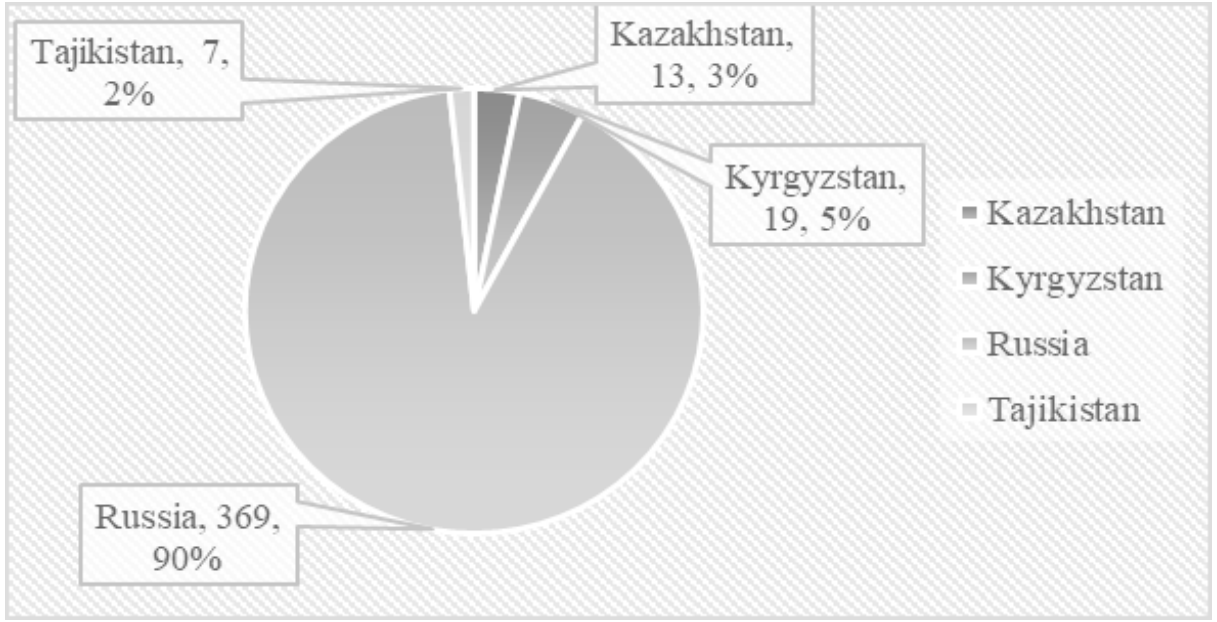

(the member state, number of master students, percentage) 
By analyzing the above data, the conclusions are drawn as follows:

1. The territory of the SCO covers parts of Central Asia, South Asia, Asia and Europe. More and more universities within the SCO framework are participating in the mechanism of the SCO University. More than half of the participating universities are located in China and Russia.

2. Within the framework of the SCO University, highly qualified talents have been trained in seven areas. What's more, the students studied in the area of "regional studies" are more than 50 percent of the total number of students.

3. From 2012 to 2018, 772 students studied in Russia, China, Kyrgyzstan, Tajikistan and Kazakhstan. The number of exchange students has steadily increased since 2012. Most Chinese students study in Russia, relatively few students study in Central Asia counties. There is a serious imbalance in student exchange within the SCO University.

In order to investigate the causes of the above data and put forward suitable ways to solve the problems the questionnaire was made for the Chinese students. The results of the analysis of 90 answers sheets to the questionnaire led to such conclusions as follows:

1. Students in the area of regional studies have an advantage in mastering Russian language, they have already studied Russian for 5 or 6 years, therefore, it is easy for them to adapt to a new life and study. However, most students majored in linguistics or literature, therefore, it is difficult for them to accept and understand knowledge in area of "Regional studies".

2. Students in other areas do not master Russian language, and study abroad in English. Although they do have short-term study of Russian language before going abroad, it is difficult for them to immediately get used to a new life. Due to cultural differences and language barrier, students have difficulty in communicating and learning.

3. According to the teaching program, the learning form mainly includes lectures, discussions and seminars, which fully develop the independence and activity of students. Most of the students are satisfied with subjects abroad, however, due to differences in the education system and the teaching program between the two universities, course connection between the two universities has not been achieved. As a matter of fact, the disciplines at the two universities do not fully coincide. However, the good thing is that most students have their own thesis supervisor to help their study and research work.

According to the findings of the analysis, we would like to propose the following ways to solve the problem

1. Strengthen cooperation between the member countries, increase quotas of Chinese government scholarships within the SCO framework, open a new Sino-foreign cooperative doctoral program, improve legislation, providing a good platform for the implementation of regional educational integration.

2. Between the two partner universities, there should be often held a discussion about the connection of disciplines, about the student's state of education, thus, in this way, a better teaching plan can be worked out. Establish a long-term mechanism of 
humanitarian exchange, strengthen international scientific exchange, create summer camps, cultural events based on cooperation between universities.

3. Attract qualified talents and make an exchange of teachers between universities to improve the level of education. Share information and experience, share advanced teaching resources, expand academic mobility. Therefore, through these methods, the competitiveness of the university and the training level of experts in participating countries may be improved.

4. It is better for candidates, whose specialty are not Russian, after the selection in a Chinese university, to take a learning of Russian language for at least six months period. For candidates majored in "Regional studies" related major courses should be offered.

Now it can be seen that political, economic, cultural and religious differences in educational integration make it more complex and diverse. The education system in each country is set differently. Therefore, there are significant differences in the number of students admitted and sent abroad. How to develop educational integration measures that serve the needs of social and regional development? How to solve problems in the implementation of regional integration in the field of education? These questions will be the main directions of the development for the next stage. Even so, for 10 years the SCO has developed significantly, the mechanisms of education are constantly being improved and updated. Mechanisms for the student and scientific-pedagogical staff exchange between the participating universities and cooperation in research between these universities were formed. Apart from that, the SCO has its own system structure. In addition to this, multidimensional development systems have been formed, for instance, the Education Ministerial Meeting, the "Education Week of the SCO Member States", the University Presidents Forum within the SCO Universities, the working meeting of the partner universities within the SCO from the Chinese side, etc.

\section{International integration of education within the SCO framework: driving force for the joint construction of "the Silk Road Economic Belt"}

The Silk Road Economic Belt (SREB) initiative proposed by Chinese President Xi Jinping in 2013 in Astana. It is a new form of deepening cooperation between China, Central Asia and Russia. The main areas of these countries are coincided between the SREB initiative and the SCO. Two initiatives will focus on infrastructure development and cooperation between countries (Li Xin, 2016). For implementation of the SREB initiative, the use of previous results and the economic cooperation mechanism of the SCO is of great significance.

China intends to facilitate the integration of the SREB with development strategies of the SCO member countries, and with the mechanism of the Eurasian Economic Union, thereby promoting openness, inclusive and common development in the region. For the purpose of building the SREB, the SCO can be made a platform for cooperation in the field of security, production facilities, finance, regional trade and public life, as 
well as a platform for strengthening interconnectivity (Li Keqiang, 2015).

The SREB initiative provides new impetus and opportunities for regional cooperation in the field of education. Similarly, the successful implementation of the initiative also requires a group of interdisciplinary personnel who do not only possess such specialized knowledge, but also provide technology, project management, quality control, international business management, logistics, finance, law, translation, international trade, etc. In addition, they also need to master knowledge of politics, economics, culture and geography of countries along the SREB initiative (Shen Pengyi, 2017).

With the help of the USCO platform, it is possible to expand the forms, scope and possibilities of language and cultural exchanges between countries of the SREB initiative; what's more, it may help to attract more students to learn the language and culture of another country. Models that combine personnel training with scientific research, such as the opening of centers for the study of cultures and languages, centers for the study of high and new technologies, as well as youth forums, seminars, summer camps for scientists, etc., can be implemented within the framework of the SCO. All of those models provide intelligent support for the construction of the SREB initiative.

Each country among the SREB is characterized by its own unique stories, customs, and religions.

One principle of the SREB initiative is respecting multiculturalism. To respect one's own culture, as well as for the national religion and culture of partners will help to effectively avoid intercultural barriers caused by insufficient knowledge of religious traditions. Therefore, in order to achieve peaceful coexistence and friendly development of cooperation, it is necessary to ensure mutual understanding between Member States on the basis of humanistic exchanges, and to eliminate obstacles and misunderstandings arising in the process of exchange and cooperation.

According to the above-mentioned information, it can be seen that the area of personnel training within the SCO framework include energy science, technology, regional geography, pedagogy, economics, etc. Within the framework of the USCO, great progress has been made in the training of interdisciplinary specialists who will serve the SREB initiative in the future. Obviously, the SREB initiative gives new challenges and goals to the SCO University.

Despite the fact that there are many of the questions above about the implementation of the students and researchers exchange mechanism, the international integration of education has become an important driving force for the implementation of the SREB initiative and remains as such. Also, it contributes to the rapid accessibility between the peoples of countries involved in the project.

\section{Conclusion}

International integration in the field of education can increase the effectiveness of internationalization of education. Universities can absorb advanced teaching experience and pedagogical system, share high-quality educational resources, promote education reform for preparing highly qualified talents with a global outlook and in- 
tercultural communicative competence in the program "foreign language + specialty". In the process of implementing the SREB initiative, the demand for talents who know country studies, who are fluent in foreign languages and poses high-level scientific skills has raised significantly. The strategy of regional educational integration within the framework of the SCO is consistent with the objectives of the SREB initiative, aimed at training highly qualified personnel with a high level of competitiveness in the international arena and with a broad outlook. Therefore, integration will become the most important force for the implementation of the SREB initiative, which serves state strategies.

\section{Финансовая поддержка}

This article is funded by China scholarship council

此项目得到中国国家留学基金委的资助

\section{Reference}

Абрамова, М.А. (2014) Интеграция в образовании, Философия образования, 3, сc. 53-63. [Abramova, M.A. (2014)'Integration in education' [Integratsiya $\mathrm{v}$ obrazovanii], Philosophy of Education, 3, pp. 5363. (In Russ.)].

Бойченко, А.А. (2007) Процессы региональной интеграции в мировой экономике, Вестник МГУ. Сер. 6, Экономика, 2, сс. 70-95. [Boichenko, A. A. (2007)'Processes of regional integration in world economy' [Protsessy regional'noi integratsii $\mathrm{v}$ mirovoi ekonomike], Moscow University Economics Bulletin, 2, pp. 70-95. (In Russ.)].

Бушмелева, Д.Б. (2015) Международная образовательная интеграция, Российский юридический журнал, 3, cc. 130-136. [Bushmeleva, D. B. (2015)'International educational integration' [Mezhdunarodnaya obrazovatel'naya integratsiya], Russian Juridical Journal, 3, pp. 130136. (In Russ.)].

Высшая школа: проблемы и перспективы: материалы 13-й Междунар. науч.-метод. конф., Минск, 20 февр. 2018 г. В 3 ч. Ч. 1. Минск: РИВШ, 2018. cc. 218-224. [Higher education: problems and prospects: proceedings of the 13th International scientific-methodical conference, Minsk, February 20, 2018. In 3 parts [Vysshaya shkola: problemy i perspektivy: materialy 13-i Mezhdunar. nauch.-metod. konf., Minsk, 20 fevr. 2018 g. V 3 ch.] (2018), part 1. Minsk: National Institute for Higher Education Publ., pp. 218-224. (In Russ.)].

Ли Синь (2016) Шанхайская организация сотрудничества: важная платформа для совместного строительства «Экономического пояса Шелкового пути», Исследования России, 2, сс. 29-37. [Li Xin (2016)'Shanghai Cooperation Organization: an important platform for the joint construction of the Silk Road Economic Belt' [Shankhaiskaya organizatsiya sotrudnichestva: vazhnaya platforma dlya sovmestnogo stroitel'stva "Ekonomicheskogo poyasa Shelkovogo puti'], 
Issledovaniya Rossii, 2, pp. 29-37. (In Russ.)].

Распоряжение Минобрнауки России о приёме иностранных граждан в Университет ШОС и Сетевой университет СНГ в 2017-2018 учебном году. [Электронный реcypc]. URL: http://uni-sco.ru/ news/62/2018_01_02.html (дата обращения: 24.04.2018) [The Decree of the Ministry of Education and Science of the Russian Federation on the admission of foreign citizens to the SCO University and the Network University of the CIS in the 2017/2018 academic year [Rasporyazhenie Minobrnauki Rossii o prieme inostrannykh grazhdan v Universitet ShOS i Setevoi universitet SNG v 2017/2018 uchebnom godu] [online]. Available at: http://uni-sco. ru/news/62/2018_01_02.html (Accessed: 24 April 2018). (In Russ.)].

Университет Шанхайской организации сотрудничества: Цели и задачи. [Электронный ресурс]. URL: http://uni-sco.ru/stat/2/stat_2.html. (дата обращения: 24.04.2018) [University of Shanghai Cooperation Organization: Goals and objectives [Universitet Shankhaiskoi organizatsii sotrudnichestva: Tseli i zadachi] [online]. Available at: http://uni-sco. ru/stat/2/stat_2.html (Accessed: 24 April 2018). (In Russ.)].

О выделении бюджетных мест на 2018-
2019 учебный год для Университета ШОС. [Электронный ресурс]. URL: Режим доступа: http://unisco.ru/news/65/2018_03_02.html (дата обращения: 24.04.2018) [On the allocation of budget places in the 2018/2019 academic year for the SCO University [O vydelenii byudzhetnykh mest na 2018/2019 uchebnyi god dlya Universiteta ShOS] [online]. Available at: http://uni-sco. ru/news/65/2018 03 02.html (Accessed: 24 April 2018). (In Russ.)].

Cappellari, Lorenzo and Claudio, Lucifora (2009)'The "Bologna Process" and college enrollment decisions', Labour Economics, 16.6, pp. 638-647. 李克强：《在上海合作组织成员国 总理第十四次会议上的讲话》 载《人民日报》2015 年 12 月 16 日. [Li Keqiang (2015)'Full text of Chinese prime minister Li eqiang's speech at 14th Meeting of Heads of Governments of the Shanghai Cooperation Organization Member States', Renmin Ribao, 16 December. (In Chinese)].

沈鹏熠. ““一带一路”倡议下我国高校 国际化人才培养研究." 职业技术 教育 31 (2017): 32-36. [Shen Pengyi (2017)'Research on training of internationalized talents in colleges and universities in China under Belt and Road Initiative[J]', Vocational and technical education, 31, pp. 32-36. (In Chinese)].

\section{Информация об авторе}

Cao Huilin - postgraduate student, the faculty of political science, Saint Petersburg state University. E-mail: huilin369@163.com (ORCID: 0000-0003-43716079. Re-searcher ID: S-1355-2018). 


\title{
МЕЖДУНАРОДНАЯ ИНТЕГРАЦИЯ ОБРАЗОВАНИЯ \\ В РАМКАХ ШОС: ДВИЖУЩАЯ СИЛА ДЛЯ СОВМЕСТНОГО СТРОИТЕЛЬСТВА «ЭКОНОМИЧЕСКОГО ПОЯСА ШЁЛКОВОГО ПУТИ»
}

\author{
Цао Хуэйлинь \\ Санкт-Петербургский государственный университет, Россия
}

\begin{abstract}
Аннотация
Проект «Экономического пояса Шёлкового пути» (ЭПШП) был представлен Си Цзиньпином осенью 2013 г. в Казахстане. Цели строительства «Экономического пояса Шёлкового пути» совпадают с задачами «Шанхайской организации сотрудничества» (ШОС). Инициатива ЭПШП получила активную поддержку стран-участников ШОС. Гуманитарное сотрудничество, особенно сотрудничество в области образования, становится одной из динамично развивающихся сфер взаимодействия в рамках ШОС. Университет ШОС, как форма интеграционного процесса в рамках ШОС, является важной движущей силой для реализации инициативы ЭПШП. В данной работе рассмотрены достигнутые успехи в международном сотрудничестве образования между вузами-участниками разных стран ШОС, а также указаны недостатки и дисбаланс в реализации подготовки кадров по разным направлениям. Анализ данных проводится как с помощью количественных, качественных, так и сравнительных методов. Для определения проблем, препятствий в подготовке кадров, а также для предложения способов их решения использован анкетный спрос. В статье выведены результаты интеграции образования в рамках ШОС и роль Университета ШОС в развитии сотрудничества между членами-государствами, а также проанализированы вызовы перед участниками-странами для реализации стратегии международной интеграции образования.

Ключевые слова: международная интеграция образования; Шанхайская организация сотрудничества; Университет ШОС; Экономический пояс Шёлковой путь; сотрудничество образования; обмен учащихся; движущая сила.
\end{abstract}

